\title{
Lymphoid abnormalities in rats with adjuvant-induced arthritis. I. Mitogen responsiveness and lymphokine synthesis
}

\author{
STEVEN C. GILMAN, JOHN F. DANIELS, ROBERT E. WILSON, \\ RICHARD P. CARLSON, AND ALAN J. LEWIS \\ From the Department of Experimental Therapeutics, Wyeth Laboratories Inc., Philadelphia, PA 19101, USA
}

SUMmARY Lewis rats injected in the hind paw with Mycobacterium butyricum develop a severe polyarthritis which shares certain features in common with rheumatoid arthritis in man. Spleen and peripheral blood mononuclear cells from rats with this form of arthritic disease proliferate poorly in vitro in response to concanavalin A (con A), phytohaemagglutinin (PHA), and pokeweed mitogen (PWM). The splenic hyporesponsiveness appears within four days of $M$. butyricum injection (three to five days prior to the development of detectable arthritis), reaches a peak 16-22 days following injection, and persists for at least 40 days. Buffalo strain rats injected with $M$. butyricum do not develop arthritis, and their spleen cells respond normally to con A, PHA, and PWM. In response to lipopolysaccharide (LPS) the synthesis of interleukin 1 (IL-1) by spleen or peritoneal macrophages from arthritic Lewis rats equalled or exceeded that of macrophages from normal rats. In contrast splenic $\mathrm{T}$ cells from arthritic rats produced reduced amounts of interleukin 2 (IL-2; T cell growth factor) in response to stimulation with PHA or con A. Moreover, con-A-activated spleen cells from arthritic rats failed to bind IL-2 and to respond to this growth factor with increased ${ }^{3} \mathrm{H}-\mathrm{TdR}$ uptake as did normal spleen cells. In-vitro treatment of 'arthritic' cells with $10^{-5} \mathrm{M}$ indomethacin did not restore to normal their reduced mitogen responsiveness, and spleen cells from normal and arthritic rats were equally sensitive to the inhibitory effects of prostaglandin $\mathrm{E}_{2}$ on con-A-induced proliferative responses. These results indicate that peripheral lymphoid function is compromised in rats with adjuvant-induced arthritis and that this functional deficit is mediated by aberrant synthesis of and response to IL- 2 by T cells of arthritic animals.

Key words: interleukin 1, interleukin 2, $\mathrm{T}$ lymphocyte, prostaglandins, rheumatoid arthritis, lymphocyte proliferation.

Rheumatoid arthritis (RA) is a disease of unknown aetiology which is characterised by chronic joint inflammation with eventual loss of joint function. ${ }^{12}$ It is a complex autoimmune disorder associated with alterations in the functional activity of macrophages, polymorphonuclear cells, B cells, and T cells within the joint capsule. ${ }^{1-5}$ Moreover, recent studies have revealed abnormal lymphoid cell function in the peripheral blood of patients with RA, including

Accepted for publication 27 June 1984

Correspondence to Dr S. C. Gilman, Immunology Unit. Wyeth Laboratories Inc, Box 8299, Philadelphia, PA 19101, USA. reduced proliferative responses to $T$ cell mitogens and altered lymphokine synthesis. ${ }^{6-10}$

Rats injected with a mixture of Mycobacterium butyricum emulsified in light mineral oil develop a severe polyarthritis which shares some features in common with RA in man. ${ }^{11}$ This model has been extremely useful in identifying chemical agents which have potential therapeutic efficacy in RA. ${ }^{12}$ In an attempt to determine the relationship between immune function and the development of arthritis in this model we have begun to examine peripheral lymphoid function in rats with this form of arthritic disease. In this report we present evidence that 
spleen cells of arthritic rats have a marked impairment in their ability to respond in vitro to mitogenic stimuli. Furthermore we have examined the temporal relationship between altered spleen cell function and the development of arthritis, the contribution of prostaglandins $\left(\mathrm{PGE}_{2}\right)$, and the possibility that altered regulation of lymphocyte responses by interleukins 1 and 2 (IL-1, IL-2) may contribute to this functional deficit. The results suggest that the deficient responsiveness of spleen cells from arthritic rats is not prostaglandin-mediated but results from a diminished ability of lymphoid cells from arthritic animals to produce and respond to IL-2.

\section{Materials and methods}

Animals. Male Lewis and Buffalo rats (150-170 g, Charles River, Wilmington, MA) were housed under standard laboratory conditions and fed food and water ad libitum.

Induction of arthritis. Groups of 8-10 rats were injected in the right hind footpad with $0.5 \mathrm{mg}$ Mycobacterium butyricum suspended in $0.1 \mathrm{ml}$ of light mineral oil (Difco Laboratories, Detroit, MI). The development of arthritis was quantitated by measuring paw volumes $(\mathrm{ml})$ at various intervals with a mercury plethysmograph. ${ }^{13}$

Cell culture. Spleens from two to four rats were removed aseptically and pooled, and single cell suspensions were prepared by passage through wire mesh screens. The cells were incubated for $10 \mathrm{~min}$ on ice with trometamol (tris)-buffered ammonium chloride (17 mM tris-146 mM NH $4 \mathrm{Cl}, \mathrm{pH} \mathrm{7.4)} \mathrm{to}$ lyse erythrocytes and were washed three times in RPMI 1640 medium (containing $20 \mathrm{mM}$ glutamine, $20 \mathrm{mM}$ HEPES, $10 \%$ bovine calf serum, $50 \mu \mathrm{g} / \mathrm{ml}$ streptomycin, $50 \mathrm{U} / \mathrm{ml}$ penicillin, and $5 \times 10^{-5} \mathrm{M}$ 2 -mercaptoethanol). Cell viability was $\geqslant 85 \%$ as determined by trypan blue exclusion. Resident peritoneal exudate cells (PEC) were obtained by lavage with $35 \mathrm{ml}$ of medium. Heparinised peripheral blood $(8-10 \mathrm{ml} / \mathrm{rat})$ was obtained by cardiac puncture, and the blood cells were washed once with medium. Peripheral blood mononuclear cells (PBL) were obtained by centrifugation of the washed cells on Ficoll-Hypaque gradients consisting of a mixture of 24 parts $13 \%$ Ficoll (Pharmacia, Piscataway, NJ) and 10 parts $33 \%$ Hypaque (Winthrop Laboratories, New York, NY).

In some experiments plastic adherent cells were isolated from the spleen or PEC by incubating $5 \times 10^{7}$ cells for $1-2 \mathrm{~h}$ in $100 \mathrm{~mm}$ diameter plastic Petri dishes. Non-adherent cells were removed by extensive washing of the plates with warm $\left(37^{\circ} \mathrm{C}\right)$ medium. The adherent cells were then removed using a rubber 'policeman', and the cells were collected by centrifugation and washed twice with medium.

Mitogen responses. Spleen cells were cultured in triplicate in 96-well microtitre plates. Each well contained $2 \times 10^{5}$ spleen cells plus $0 \cdot 02-2 \mu \mathrm{g}$ concanavalin A (con A; Miles Laboratories, Elkhart, IN), 2-20 $\mu \mathrm{g}$ phytohaemagglutinin (PHA, Wellcome, Diagnostics, Dartford, UK), or 0.002-0.02 $\mu \mathrm{g}$ pokeweed mitogen (PWM; Sigma Chemical Co., St Louis, MO) in a total volume of $0.2 \mathrm{ml}$. The plates were incubated at $37^{\circ} \mathrm{C}$ in a humidified atmosphere of $5 \% \mathrm{CO}_{2}$ in air for four days. Each culture received $1 \mu \mathrm{Ci}$ of tritiated thymidine $\left({ }^{3} \mathrm{H}\right.$-TdR) $8 \mathrm{~h}$ prior to harvesting on to glass fibre filters (Skatron multiharvester, Skatron, Inc., Sterling, VA) which were then processed for liquid scintillation counting. In some experiments prostaglandin $\mathrm{E}_{2} \quad \mathrm{PGE}_{2}$, Sigma Chemical Co., St Louis, MO) at $10^{-5}-10^{-7}$ $M$ concentration was added to the wells at the initiation of the culture period. $\mathrm{PGE}_{2}$ was dissolved in absolute ethanol and diluted in medium; identical concentrations of ethanol alone had no effect in any experiment.

Lymphokine production and assay. For production of IL-1, $5 \times 10^{6}$ plastic adherent PEC or spleen cells were cultured in $1 \mathrm{ml}$ of medium containing 10 or $100 \mu \mathrm{g} / \mathrm{ml}$ of lipopolysaccharide (LPS, Escherichia coli, No. 0111:B4, Sigma Chemical Co., St Louis, MO). After 24-48 h the supernatant fluids from these cultures were collected and passed through a $0 \cdot 2 \mu \mathrm{m}$ filter. IL-1 activity was measured with a thymocyte costimulator assay in which $5 \times 10^{5}$ Lewis rat thymocytes $/ 0.2 \mathrm{ml}$ medium were cultured for three days with $20 \mu \mathrm{g} / \mathrm{ml}$ PHA plus varying dilutions of test supernatant. ${ }^{14}$ IL-1 activity was calculated by subtracting the disintegrations per minute $(\mathrm{dpm})$ of thymocytes cultured with PHA alone from the dpm in thymocytes cultured with PHA plus test supernatant $(\triangle \mathrm{dpm})$. Supernates from LPS-activated adherent cell cultures were routinely negative when tested for IL- 2 by the CTLL-2 assay (see below).

The ability of spleen cells to produce IL-2 was assessed by culturing $1 \times 10^{6}$ spleen cells for $24 \mathrm{~h}$ in $1.0 \mathrm{ml}$ medium containing $0 \cdot 1-1 \mu \mathrm{g}$ con $\mathrm{A}$ or $50-100$ $\mu \mathrm{g} / \mathrm{ml}$ PHA. Supernatant fluids were then tested for IL-2 activity by the IL-2-dependent mouse cytotoxic $\mathrm{T}$ cell line, CTLL-2, as previously described. ${ }^{15}$ For use in some experiments rat IL-2 was partially purified by passing spleen cell con A supernatant through an AcA 54 column equilibrated in phosphate-buffered saline (PBS). Column fractions which showed activity in the CTLL-2 assay (10 000$15000 \mathrm{MW}$ range) were pooled, concentrated, and dialysed extensively against PBS. In some experi- 


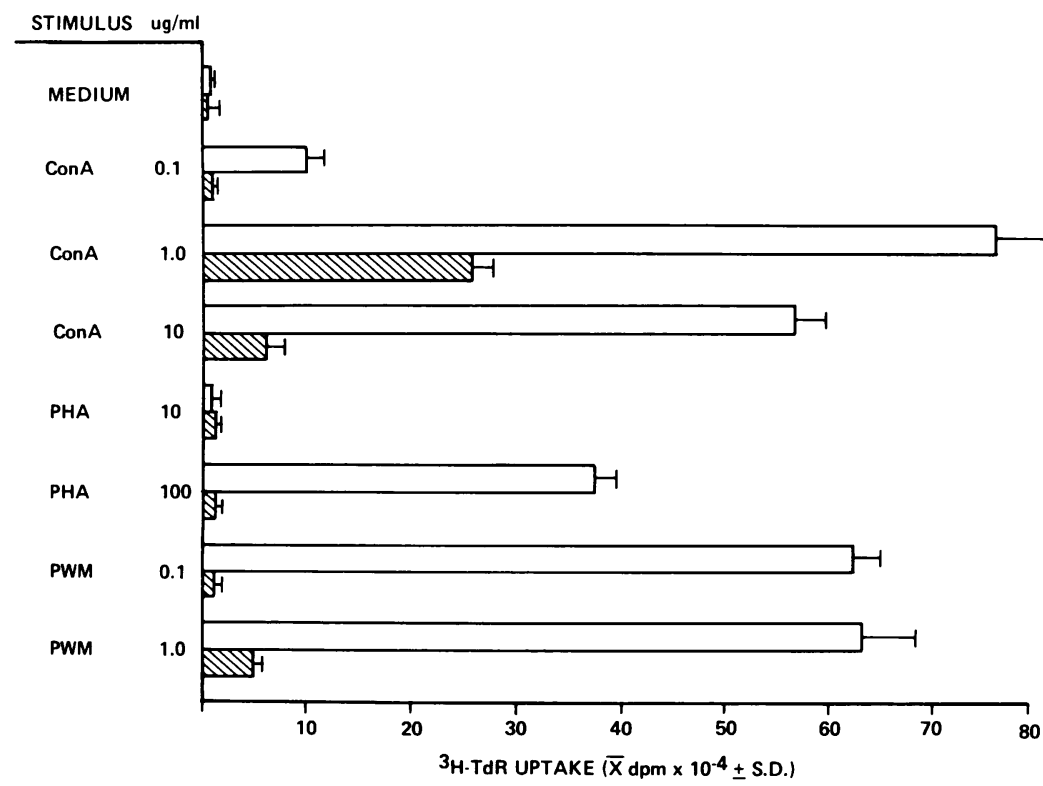

Fig. 1 Mitogen proliferative responses of spleen cells from normal and arthritic rats. $2 \times 10^{5}$ spleen cells from normal $(\square)$ and arthritic rats 16 days after $\mathrm{M}$. butyricum injection (1) were cultured for four days with the indicated concentrations of con $A$, $P H A$, and $P W M$ and were pulsed with $1 \mu \mathrm{Ci}{ }^{3} \mathrm{H}-\mathrm{TdR}$ for the final $8 \mathrm{~h}$ of culture. Bars represent the mean ${ }^{3} \mathrm{H}$-TdR uptake $(\mathrm{dpm}) \pm S D$ for triplicate cultures. All differences between the normal and 'arthritic' cells were statistically significant ( $p \leqslant 0 \cdot 05$, Dunnett's test) except for the cultures without mitogen (medium controls) and $10 \mu \mathrm{g} / \mathrm{ml}$ PHA group.

ments a partially purified rat IL-2 preparation purchased from Collaborative Research (Lexington, MA) was used with similar results. One unit of IL-2 was defined as the amount of IL-2 needed to induce one-half maximal proliferation of CTLL-2 cells. ${ }^{15}$

Statistical analyses. All data were analysed by 2-way analysis of variance with the significance between means determined by Dunnett's comparison $(p \leqslant 0.05$ considered significant $)$.

\section{Results}

Proliferative responses of spleen cells from normal and arthritic rats. Spleen cells from rats with severe arthritis, 16 days after $M$. butyricum injection,

Table 1 Proliferative response of peripheral blood mononuclear cells from normal and arthritic rats*

\begin{tabular}{lccc}
\hline Group & \multicolumn{3}{l}{ Con $A$ concentration } \\
\cline { 2 - 4 } & $0 \cdot 1 \mu \mathrm{g} / \mathrm{ml}$ & $1.0 \mu \mathrm{g} / \mathrm{ml}$ & $10 \cdot 0 \mu \mathrm{g} / \mathrm{ml}$ \\
\hline Normal & $61 \cdot 3 \pm 7.7$ & $41.4 \pm 14 \cdot 0$ & $40.7 \pm 4.4$ \\
Arthritic & $4 \cdot 8 \pm 1 \cdot 6 \dagger$ & $38.0 \pm 4.4$ & $8.6 \pm 1 \cdot 3 \dagger$ \\
\hline
\end{tabular}

${ }^{*}$ Mononuclear cells were obtained from the peripheral blood of normal rats or rats with arthritis 16 days after $M$. butyricum injection (two animals/group). Numbers indicate the mean ${ }^{3} \mathrm{H}-\mathrm{TdR}$ uptake $(\mathrm{dpm}) \times 10^{-3} \pm \mathrm{SD}$ of triplicate cultures.

†Significantly different from ${ }^{3} \mathrm{H}-\mathrm{TdR}$ uptake in cultures of normal cells $(p<0.05$, Dunnett's test). proliferated poorly in vitro when stimulated with con A, PHA, or PWM (Fig. 1). The magnitude of this proliferative defect ranged from 50 to $95 \%$ and was statistically significant and highly reproducible. The reduced proliferative capacity of 'arthritic' spleen cells was not due to a shift in the mitogen dose-response curve or kinetics of the in-vitro response, as the defect was readily apparent regardless of antigen concentration (Fig. 1) or the day the cultures were pulsed with ${ }^{3} \mathrm{H}$-TdR (data not shown). No difference was observed in the spontaneous proliferation (for example, in the absence of mitogen) between normal and 'arthritic' cells. The proliferative defect was not restricted to spleen cells, as peripheral blood cells from arthritic animals showed a similar dose-dependent hyporesponsiveness to in-vitro mitogen stimulation (Table 1).

Kinetics of spleen cell hyporesponsiveness in relation to the development of arthritis. Fig. 2 shows that the time course of development of arthritis (as measured by paw oedema) and the development of splenic hyporesponsiveness to mitogenic stimulation were similar. Within $24 \mathrm{~h}$ of injection of $M$. butyricum a non-specific inflammatory response occurred in the injected paw. By day 8-10 both the injected and uninjected paws began to show a significant arthritic response, which increased rapidly until day $16-22$, after which no further increases in paw oedema were noted. Spleen cell hyporesponsiveness to PHA in vitro developed in parallel with the arthritic response but was first evident by day 4 , 


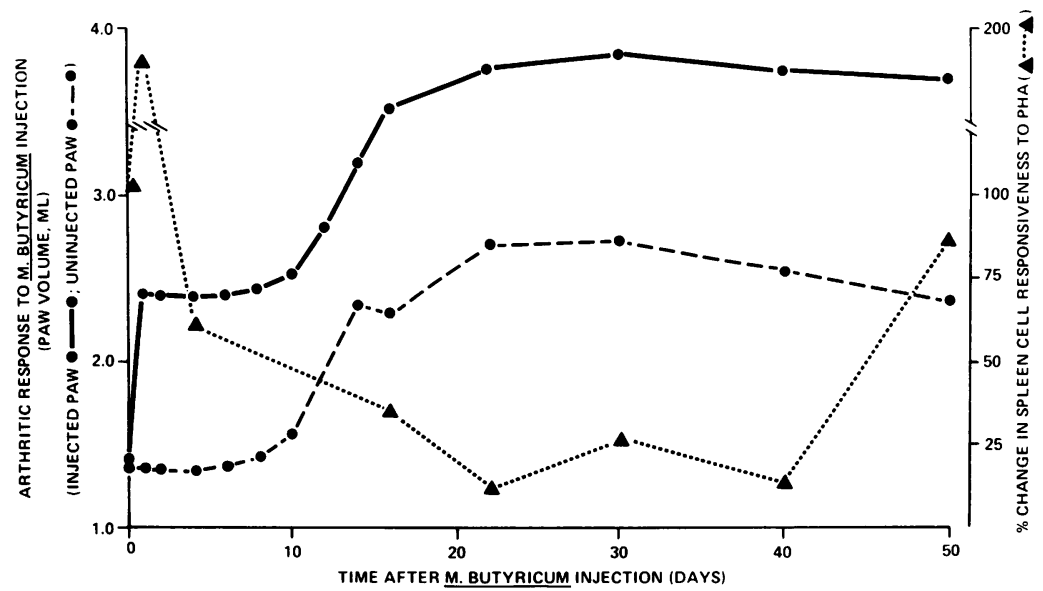

Fig. 2 Temporal relationship between the development of an arthritic response and spleen cell hyporesponsiveness to PHA in rats injected with $\mathrm{M}$. butyricum. Rats were injected on day 0 in the right hind paw with a homogenised suspension containing $0.5 \mathrm{mg}$ M. butyricum. Paw oedema in the injected (-) and uninjected $(\mathbf{0}--)$ ) paws was measured at various intervals with a mercury plethysmograph ( $n=10$ animals per point). On days 1, 4, 16, 22, 30, 40, and 50 after injection two animals were killed and their spleens were assessed for in-vitro proliferative responsiveness to $50 \mathrm{\mu g} / \mathrm{ml} \mathrm{PHA}$ $(\Delta \ldots . .$.$) as described in the legend to Fig. 1$. Results of proliferative assay are expressed as a percentage change in ${ }^{3} H-T d R$ uptake (dpm) relative to the response of normal spleen cells assayed on the same day. Similar results were obtained with con $A$ as the in-vitro stimulus.

3-5 days before paw oedema was detectable. By day 22 the proliferative response of 'arthritic' spleen cells was about $10 \%$ that of the control response and remained at this level for at least an additional 20 days. Interestingly, a transient increase in spleen cell proliferative response was observed $24 \mathrm{~h}$ after $M$. Butyricum injection which was possibly associated with the acute inflammatory response.

Deficient spleen cell mitogen responses were observed only in animals which developed arthritis following $M$. butyricum injection. Buffalo rats injected with $M$. butyricum did not develop arthritis, and their spleen cells responses to mitogens were normal (Table 2).

Interleukin synthesis by spleen cells from norma and arthritic rats. Since interleukins 1 and 2 are important soluble mediators necessary for optimal in-vitro $\mathrm{T}$ cell proliferation, ${ }^{16}{ }^{17}$ we examined the possibility that 'arthritic' spleen cells were deficient in their ability to produce or utilise these lymphokines.

Fig. 3 shows that LPS-stimulated adherent spleen cells from arthritic rats produced high levels of IL-1-like activity. In separate experiments IL-1

Table 2 Correlation between the development of arthritis and diminished spleen cell proliferative responses in rats injected with M. butyricum

\begin{tabular}{|c|c|c|c|c|c|c|c|c|}
\hline \multirow{3}{*}{$\begin{array}{l}\text { Rat } \\
\text { strain }\end{array}$} & \multirow{3}{*}{$\begin{array}{l}\text { M. butyricum } \\
\text { injection }\end{array}$} & \multirow{3}{*}{$\begin{array}{l}\text { Arthritic } \\
\text { response }\end{array}$} & \multicolumn{6}{|c|}{ Spleen cell proliferative response } \\
\hline & & & \multicolumn{2}{|l|}{$\operatorname{Con} A$} & \multicolumn{2}{|l|}{$P H A$} & \multicolumn{2}{|l|}{$P W M$} \\
\hline & & & $\begin{array}{l}{ }^{3} \mathrm{H}-T d R \\
\text { uptake }\end{array}$ & $\begin{array}{l}\% \\
\text { change }\end{array}$ & $\begin{array}{l}{ }^{3} H-T d R \\
\text { uptake }\end{array}$ & $\begin{array}{l}\% \\
\text { change }\end{array}$ & $\begin{array}{l}{ }^{3} H-T d R \\
\text { uptake }\end{array}$ & $\begin{array}{l}\% \\
\text { change }\end{array}$ \\
\hline $\begin{array}{l}\text { Lewis } \\
\text { Lewis }\end{array}$ & 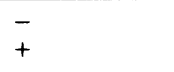 & - & $\begin{array}{c}178 \pm 30 \\
5 \pm 1\end{array}$ & $\downarrow \overline{97 \dagger}$ & $\begin{array}{r}183 \pm 12 \\
48 \pm 16\end{array}$ & $\downarrow \overline{74 \dagger}$ & $\begin{array}{c}70 \pm 11 \\
8 \pm 2\end{array}$ & $\downarrow \overline{94 \dagger}$ \\
\hline $\begin{array}{l}\text { Buffalo } \\
\text { Buffalo }\end{array}$ & $\begin{array}{l}- \\
+\end{array}$ & $\begin{array}{l}- \\
-\end{array}$ & $\begin{array}{l}262 \pm 68 \\
272 \pm 56\end{array}$ & $\uparrow_{4}^{-}$ & $\begin{array}{l}580 \pm 10 \\
731 \pm 56\end{array}$ & $\uparrow \overline{26}$ & $\begin{array}{l}609 \pm 99 \\
752 \pm 22\end{array}$ & $\uparrow \overline{23}$ \\
\hline
\end{tabular}

*Groups of two Lewis or Buffalo rats were injected in the right hind paw with $M$. butyricum and 16 days later were assessed for the development of arthritis (oedema in the uninjected paw) and for the ability of their spleen cells to proliferate in vitro in response to con $A$ $(0.1 \mu \mathrm{g} / \mathrm{ml})$, PHA $(50 \mu \mathrm{g} / \mathrm{ml})$, and PWM $(0.1 \mu \mathrm{g} / \mathrm{ml})$. Numbers indicate the mean dpm ${ }^{3} \mathrm{H}-\mathrm{TdR}$ uptake $\times 10^{-3} \pm \mathrm{SD}$ for triplicate cultures. $t p \leqslant 0.05$ compared to uninjected controls of the same strain (Dunnett's test). Arrows indicate direction of percentage change. 


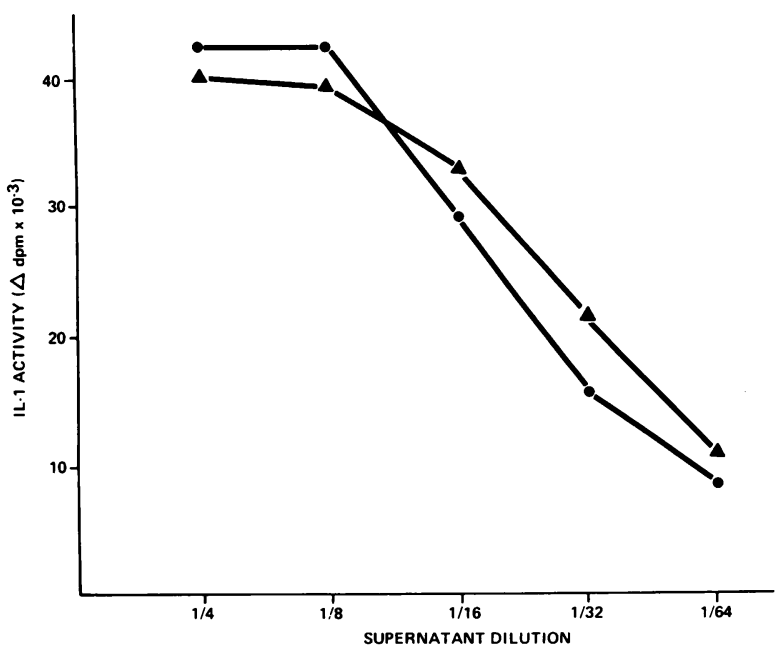

Fig. 3 Production of IL-1 by splenic macrophages from normal and arthritic rats. Adherent cells $\left(5 \times 10^{6} / \mathrm{ml}\right)$ from the spleens of normal rats $(-)$ ) and rats with arthritis 16 days after $\mathrm{M}$. butyricum injection $(\mathbf{\Delta - \mathbf { \Delta }})$ were cultured with $10 \mu \mathrm{g} / \mathrm{ml} \mathrm{LPS}$ for 24 hours. Cell-free supernatants were collected and filter-sterilised. IL-1 activity in the supernatant was estimated by a thymocyte costimulator assay in which $5 \times 10^{5}$ rat thymocytes were cultured with $20 \mu \mathrm{g} / \mathrm{ml}$ PHA plus varying concentrations of test supernatant and proliferation $\left({ }^{3} \mathrm{H}-\mathrm{TdR}\right.$ uptake) assessed on day 3. $\triangle d p m=d p m$ of ${ }^{3} H-T d R$ uptake in thymocytes cultured with test supernatant plus PHA minus the dpm of thymocytes cultured with $P H A$ alone. The results are representative of two experiments in which no differences in IL-1 production were observed between normal and arthritic splenic macrophages. Similar results were obtained with PEC. However, in two experiments a modest but statistically significant increase in $I L-1$ production by 'arthritic' macrophages was observed.

synthesis by arthritic cells was either equivalent to or significantly greater than IL-1 synthesis by normal cells, and this was true of LPS-stimulated adherent cells obtained from spleen or peritoneal cells.

In contrast, con A- or PHA-stimulated spleen cells of arthritic rats produced significantly lower levels of IL-2 compared with their normal counterparts (Fig. 4). The addition of exogenous IL-2 to 'arthritic' spleen cells did not restore to normal their ability to proliferate; indeed spleen cells of arthritic animals responded poorly or not at all to exogenous IL-2 (Table 3). Furthermore, whereas con-Aactivated spleen cells from normal animals efficiently absorbed IL-2, con-A-activated spleen cells from arthritic animals did not (Fig. 5).

Role of prostaglandins in hyporesponsiveness of spleen cells from arthritic rats. Prostaglandins are established mediators of inflammatory responses and have been long suspected to play an important role in articular destruction. ${ }^{12}$ In addition they suppress certain in-vitro immune functions, including mitogen proliferative responses and IL-2 synthesis. ${ }^{819}$ Therefore we examined the role of prostaglandins in the reduced proliferative responses of spleen cells from arthritic rats. Table 4 shows that treatment of 'arthritic' spleen cells in vitro with $10^{-5} \mathrm{M}$ indomethacin, an inhibitor of prostaglandin synthesis, ${ }^{20}$ improved to some degree the ability of these cells to produce IL-2. However, indomethacin treatment did not restore this defect in 'arthritic' cells to normal levels, and IL-2 synthesis by normal cells was also increased by indomethacin treatment (Table 4).

The effects of exogenous $\mathrm{PGE}_{2}$ on the proliferative responses of normal and 'arthritic' spleen cells was examined by adding $10^{-5} \mathrm{M}-10^{-7} \mathrm{M} \mathrm{PGE}_{2}$ to con A-stimulated cultures and measuring proliferation ( ${ }^{3} \mathrm{H}$-TdR uptake) on day $4.10^{-6} \mathrm{M}$ and $10^{-7} \mathrm{M} \mathrm{PGE}_{2}$ did not significantly alter the response of normal or

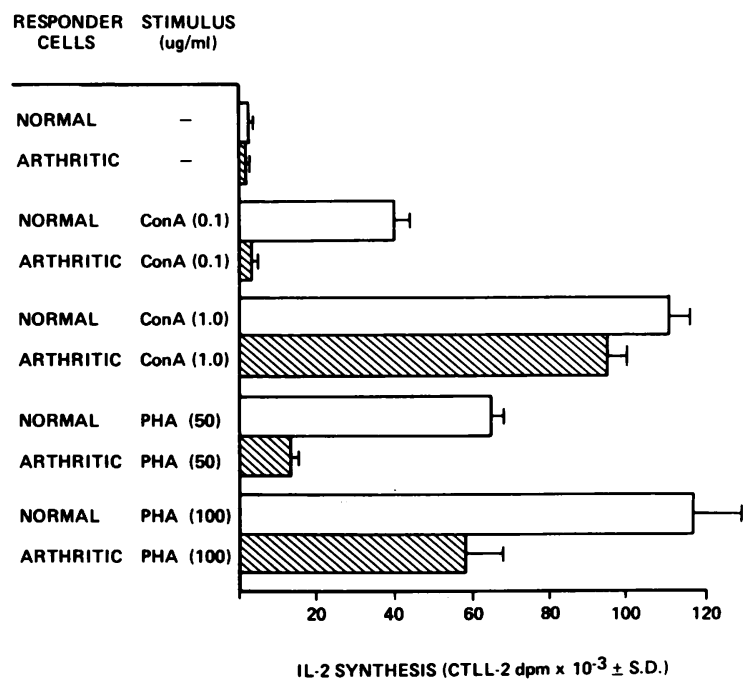

Fig. 4 IL-2 synthesis by spleen cells from normal and arthritic rats. Spleen cells from normal rats ( $\square$ ) and rats

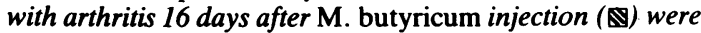
cultured $\left(1 \times 10^{6} / \mathrm{ml}\right)$ for $24 \mathrm{~h}$ with the indicated concentrations of con A or PHA. Cell-free supernatants were collected, filter-sterilised, and assayed for IL-2 in the CTLL-2 assay. Samples were assayed at dilutions of 1/4-1/256 and the data shown are dilutions of 1/8. Bars represent the mean ${ }^{3} \mathrm{H}-\mathrm{TdR}$ uptake (dpm) in CTLL-2 cells $\pm S D$. All differences in IL-2 synthesis by normal and 'arthritic' cells were significant ( $p \leqslant 0 \cdot 05$, Dunnett's test) except for the medium and $1 \mu \mathrm{g} / \mathrm{ml}$ con A groups. 
Table 3 Effects of exogenous IL-2 on con-A-induced proliferative response of spleen cells from normal and arthritic rats*

\begin{tabular}{|c|c|c|c|c|}
\hline \multirow[t]{2}{*}{$I L-2$ added } & \multicolumn{2}{|c|}{ Experiment 1} & \multicolumn{2}{|c|}{ Experiment 2} \\
\hline & Normal & Arthritic & Normal & Arthritic \\
\hline 一 & $194 \pm 6$ & $41 \pm 3$ & $68 \pm 15$ & $17 \pm 3$ \\
\hline $0.5 \mathrm{U} / \mathrm{ml}$ & $270 \pm 6 \dagger$ & $57 \pm 9$ & $136 \pm 12 \dagger$ & $11 \pm 2$ \\
\hline $5 \cdot 0 \mathrm{U} / \mathrm{ml}$ & $515 \pm 54 \dagger$ & $55 \pm 13$ & $387 \pm 37 \dagger$ & $6 \pm 1$ \\
\hline
\end{tabular}

*Spleen cells from normal rats or arthritic rats 16 (experiment 1 ) or 17 (experiment 2) days after $M$. butyricum injection were cultured for four days with $0 \cdot 1 \mu \mathrm{g} / \mathrm{ml}$ con A plus $0-5 \mathrm{U} / \mathrm{ml} \mathrm{IL-2}$ and pulsed with ${ }^{3} \mathrm{H}$-TdR for the final $8 \mathrm{~h}$ of culture. Numbers represent mean ${ }^{3} \mathrm{H}$-TdR uptake $(\mathrm{dpm}) \times 10^{-3} \pm \mathrm{SD}$ for triplicate cultures

†Significantly different from ${ }^{3} \mathrm{H}$-TdR uptake in cultures without added IL-2 $(p \leqslant 0 \cdot 05$, Dunnett's test $)$.

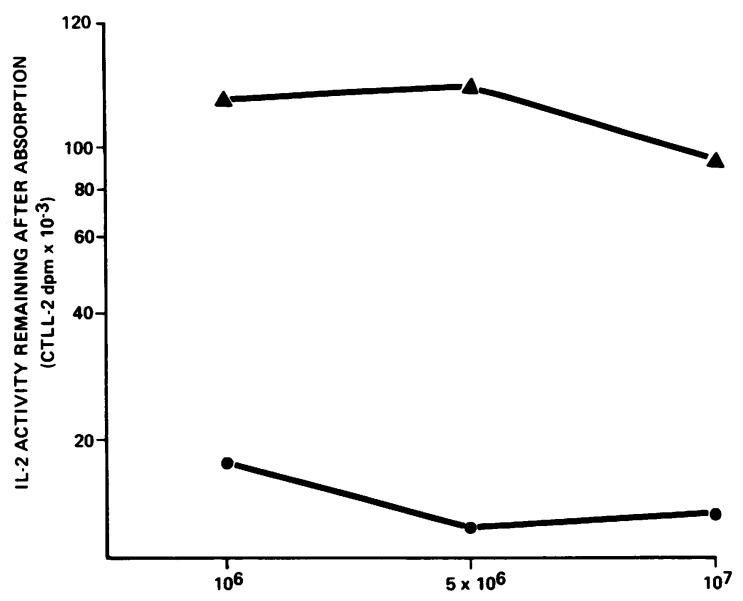

NUMBER OF CON A BLASTS USED FOR ABSORPTION

Fig. 5 Absorption of IL-2 by con A-stimulated spleen cells from normal and arthritic rats. Spleen cells from normal rats $(-)$ or rats with arthritis 16 days after $\mathrm{M}$. butyricum injection $(\boldsymbol{\Delta}-\mathbf{\Delta})$ were cultured $\left(1 \times 10^{\circ}\right.$ cells $/ \mathrm{ml}$ ) with $0 \cdot 1 \mathrm{\mu g} / \mathrm{ml}$ con $A$. On day 4 viable cells were collected by centrifugation on Ficoll-Hypaque gradients. Varying numbers of the recovered cells were resuspended in $0.5 \mathrm{ml}$ of a 1/150 dilution of partially purified rat IL-2. After a $4 \mathrm{~h}$ incubation at $37^{\circ} \mathrm{C}$ the cells were removed by centrifugation and residual IL-2 measured in the CTLL-2 assay (tested at a 1/4 dilution). All differences between normal and 'arthritic' cells were significant $(p \leqslant 0 \cdot 05$, Dunnett's test).
Table 4 Effects of indomethacin on IL-2 synthesis by con $A$-activated spleen cells from normal and arthritic rats*

\begin{tabular}{lll}
\hline Spleen cells & \multicolumn{1}{l}{ IL-2 synthesis } & $\left(C T L L-2 d p m \times 10^{-3} \pm S D\right)$ \\
\cline { 2 - 3 } & Control & Indomethacin \\
\hline Normal & $40 \pm 4$ & $61 \pm 6$ \\
Arthritic & $3 \pm 1 \dagger$ & $21 \pm 2 \dagger$
\end{tabular}

*Spleen cells from normal rats or rats with arthritis 16 days following $M$. butyricum injection (three animals/group) were cultured for $24 \mathrm{~h}$ with $0.1 \mu \mathrm{g} / \mathrm{ml}$ con A in the presence or absence (control) of $10^{-5} \mathrm{M}$ indomethacin. Supernatant fluids were collected and assayed for IL-2 activity in the CTLL-2 assay.

$\dagger$ Significantly different from normal group ( $p \leqslant 0 \cdot 05$, Dunnett's test).

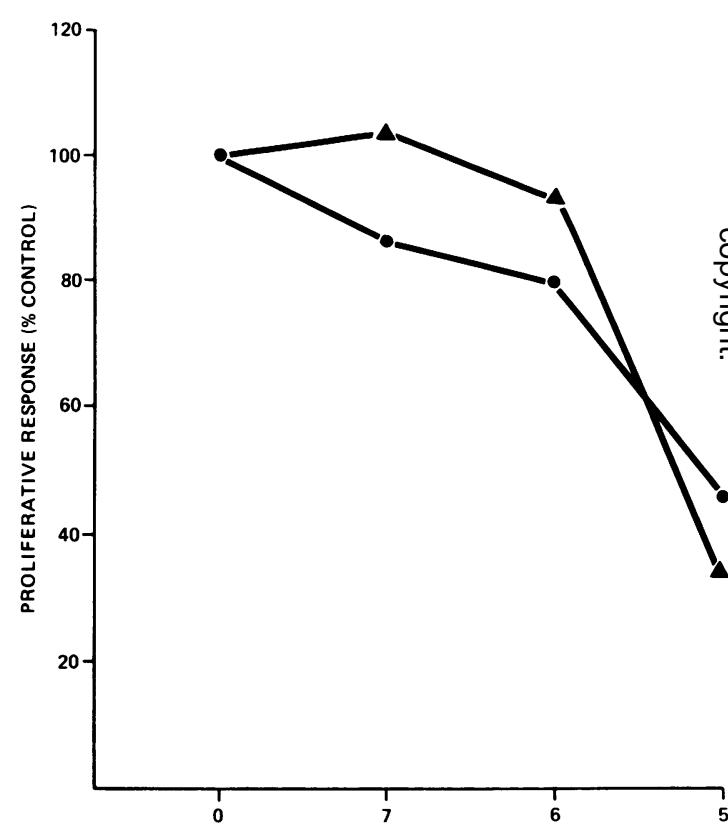

PGE $_{2}$ CONCENTRATION $(-\log M)$

Fig. 6 Effect of exogenous $P G E_{2}$ on in vitro proliferative response of spleen cells from normal and arthritic rats to con $A .2 \times 10^{5}$ spleen cells from normal rats and rats with arthritis 16 days after $\mathrm{M}$. butyricum injection $(\Delta-\Delta)$ were cultured for four days with $0.1 \mu \mathrm{g} / \mathrm{ml}$ con A plus $10^{-7} \mathrm{M}-10^{-5} \mathrm{M} P G E_{2}$ and pulsed with $1 \mu \mathrm{Ci}{ }^{3} \mathrm{H}-\mathrm{TdR}$ for the final $8 \mathrm{~h}$ of culture. Data are plotted as a percent change of ${ }^{3} H-T d R$ uptake in cultures containing $P G E_{2}$ relative to uptake in cultures without $P G E_{2}$. Differences between the response of normal and arthritic cells to $P G E_{2}$ were not significant ( $p>0.05$, Dunnett's test). 
'arthritic' cells to con A (Fig. 6). However, $10^{-5} \mathrm{M}$ $\mathrm{PGE}_{2}$ significantly reduced proliferation of both normal and 'arthritic' cells to the same degree (50-70\% inhibition of ${ }^{3} \mathrm{H}-\mathrm{TdR}$ uptake).

\section{Discussion}

The present study has shown that (1) spleen and peripheral blood lymphocytes from rats with arthritis due to $M$. butyricum injection proliferate poorly in vitro in response to con A, PHA, or PWM; (2) this state of hyporesponsiveness occurs with similar kinetics to and is correlated with the development of an articular arthritis; (3) splenic and peritoneal macrophages from arthritic rats produce normal or augmented levels of IL-1 in response to LPS; (4) con A- or PHA-stimulated cells from arthritic rats produce significantly lower amounts of IL-2 and, moreover, fail to bind and respond to this lymphokine; (5) indomethacin treatment of arthritic spleen cells does not restore to normal their deficient IL-2 synthesis; and (6) spleen cells from normal or arthritic rats are equally sensitive to the inhibitory effects of $\mathrm{PGE}_{2}$ on lymphocyte proliferation. We conclude that during the course of a $M$. butyricuminduced arthritic response a state of refractoriness of spleen and peripheral blood cells to in-vitro mitogen stimulation develops and this hyporesponsiveness is mediated, at least in part, by the reduced ability of 'arthritic' cells to produce and respond to IL-2. We suggest that lymphokine abnormalities play a role in the immunological imbalance observed in this experimental model of arthritic disease.

Our results confirm the findings of others that spleen cells from arthritic rats respond poorly in vitro to PHA and con A. ${ }^{21-23}$ In addition we have examined these observations by documenting that a similar phenomenon occurs with a T-dependent B cell mitogen (PWM) and by dissecting the role of prostaglandin and lymphokine synthesis/responsiveness in mediating this splenic hyporesponsiveness.

Despite the generally observed immunepotentiating or adjuvant effect of Mycobacteria spp. ${ }^{24}$ some investigators have reported decreased spleen cell proliferative responses in mice injected with large doses ( $\geqslant 3 \mathrm{mg}$ ) of BCG. ${ }^{2526}$ Our data, however, indicate that the decreased spleen cell responsiveness in arthritic rats is not simply a consequence of exposure of the animals to $M$. butyricum but is in fact related to the development of an arthritic response. Thus spleen cell reactivity is normal in $M$. butyricum-injected animals which fail to develop arthritis, and both splenic hyporesponsiveness and arthritogenesis share a close temporal relationship. Moreover, our rats received 30-40-fold less mycobacterium (on a body weight basis) than is required to reduce splenic hyporeactivity in mice. ${ }^{26}$

Because $\mathrm{T}$ cell proliferation in vitro is dependent on the synthesis and utilisation of IL-1 and IL- 2,1617 we examined the possibility that a dysregulation of this lymphokine cascade system could contribute to the reduced immune function in arthritic rats. In response to LPS the synthesis of IL-1 by splenic or peritoneal macrophage from arthritic rats equalled or exceeded that of macrophages obtained from normal animals. Thus we could not account for the proliferative defect of arthritic cells by an insufficient availability of IL-1. While we do not know the significance of the increased synthesis of IL-1 by 'arthritic' cells observed in some experiments, this finding is provocative in the light of recent indications that IL-1 may be an inflammatory mediator in rheumatoid disease. IL-1 is present in synovial fluid, stimulates collagenase and $\mathrm{PGE}_{2}$ production, mediates fever, and stimulates the release by liver cells of acute phase protein. ${ }^{16}$

Spleen cells from arthritic rats produced significantly reduced amounts of IL-2 following stimulation with con A or PHA. However, the data suggest that the reduced IL-2 synthetic response is not physiologically relevant, since by-passing this IL-2 synthetic defect by providing an exogenous source of IL-2 did not restore their proliferative capacity. In addition the reduced synthesis of IL-2 was in some cases not statistically significant (see Fig. 4, 1 $\mu \mathrm{g} / \mathrm{ml}$ con A), and yet the proliferative response of the same cells was always dramatically reduced. Furthermore con A-stimulated spleen cells from arthritic rats failed to bind IL-2 or respond to this factor with increased ${ }^{3} \mathrm{H}$-TdR uptake as did normal cells. Our interpretation of these data is that the principal defect in 'arthritic' cells is the failure to produce receptors for IL-2 and thereby receive the IL-2-mediated growth signal. Confirmation of this hypothesis awaits more complete IL-2 receptor analysis, when monoclonal antibody to the rat IL-2 receptor becomes available (for example, the human anti-Tac equivalent). ${ }^{27}$ In addition we cannot at present rule out any post IL-2 receptor defects in 'arthritic' cells, such as signal processing or second messenger systems.

Prostaglandins, particularly of the E series, are important mediators of inflammatory responses and are known to inhibit a variety of immune functions, including mitogen-induced proliferation and IL-2 synthesis. 11819 In the present study two approaches were used to ascertain the possible role of prostaglandins in the reduced mitogen responsiveness of arthritic rat spleen cells. Firstly, inhibiting prostaglandin synthesis with indomethacin (at a dose which inhibits $>90 \%$ of $\mathrm{PGE}_{2}$ or $\mathrm{PGF}_{1 \alpha}$ synthesis ${ }^{28}$ ) did 
not restore to normal the reduced responsiveness of 'arthritic' cells. Secondly, spleen cells from normal and arthritic rats were equally sensitive to the inhibitory effects of exogenously added $\mathrm{PGE}_{2}$. Hence prostaglandin-mediated suppression of $\mathrm{T}$ cell reactivity cannot account for the reduced mitogen responsiveness of 'arthritic' spleen cells. Hassler et al. ${ }^{29}$ reported that peripheral blood cells from RA patients were exquisitely more sensitive to the effects of $\mathrm{PGE}_{1}$ or $\mathrm{PGE}_{2}$ than normal cells.

Suppressor cells have been suggested as playing an important role in various autoimmune and immunodeficiency disorders. ${ }^{30}$ One possible explanation for the reduced IL-2 synthesis and responsiveness of 'arthritic' cells is the presence of an active suppressor element. Indeed an adherent suppressor cell has been described in rats with this form of arthritic disease, ${ }^{23}$ and we are currently examining the potential role of this type of cell in the lymphokine defects characterised here.

While we have described alterations in the function of spleen and peripheral blood cells from arthritic rats, we do not know what relevance these findings have to the articular events leading to joint destruction. From our present knowledge no definitive statements of the contribution of such peripheral lymphoid abnormalities to joint pathology can be made. In this regard, however, it is provocative that successful pharmacological therapy (that is, a reduction in articular inflammation) is associated with an improvement in peripheral lymphoid function in this model (S. Gilman, manuscript in preparation) and humans with RA. ${ }^{31}$

Reduced mitogen responsiveness and IL-2 synthesis/responsiveness is not unique to arthritic rats. Similar functional deficits have been described in systemic lupus erythematosus (SLE), acquired immune deficiency syndrome (AIDS), and aged animals and humans. ${ }^{32-36}$ Moreover, there are numerous reports of $T$ cell dysfunction in RA patients. ${ }^{6-10} 31$ Thus aberrant regulation of the IL-1/IL-2 lymphokine cascade is a common underlying feature of autoimmune and immunodeficiency disorders. However, further studies are required to determine the precise relevance of such immune defects to clinical expression of these important human diseases.

We thank Mr Louis Datko for technical assistance and Ms Dolores Lewis for typing this manuscript.

\section{References}

1 Zvaifler $\mathrm{N} \mathrm{J}$. The immunopathology of joint inflammation in rheumatoid arthritis. Adv Immunol 1973; 16: 265-336.

2 Ziff M. Systemic rheumatoid disease: immunological aspects. Inflammation Res 1982; 3: 123-39.
3 Janossy G, Duke O. Poulter L W, Panayi G, Bofill M, Goldstein G. Rheumatoid arthritis: a disease of T lymphocyte/ macrophage immunoregulation. Lancet 1983; i: 839-42.

4 Klareskog L, Forsum U, Scheynius A, Kabelitz D, Wigzell H. Evidence in support of a self-perpetuating HLA-DR-dependent delayed-type hypersensitivity reaction in rhcumatoid arthritis. Proc Natl Acad Sci USA 1982; 79: 3632-6.

5 Duke O, Panayi G S, Janossy G, Poulter L W. An immunohistological analysis of lymphocyte subpopulations and their microenvironment in the synovial membranes of patients with rheumatoid arthritis using monoclonal antibodies. Clin Exp Immunol 1982; 49: 22-30.

6 Rawson A J, Huang T C. Lymphocytes in rhcumatoid arthritis. I. Responses to allogeneic cells and to phytomitogens. Clin Exp Immunol 1974; 16: 41-6.

7 Silverman H A, Johnson J S, Vaughan J H, McGlamory J C. Altered lymphocyte reactivity in rheumatoid arthritis. Arthritis Rheum 1976; 19: 509-15.

8 Seitz M, Deimann W, Gram N. Hunstein W D. Gemsa D. Characterization of blood mononuclear cells of arthritis patients. 1. Depressed lymphocyte proliferation and enhanced prostanoid release from monocytes. Clin Immunol Immunpathol 1982; 25: 405-16.

9 Bardwick P A, Bluestein H G, Zvaifler N J, Deppler J M, Seegmiller J E. Altered regulation of Epstein-Barr virusinduced lymphoblast proliferation in rheumatoid arthritis lymphoid cells. Arthritis Rheum 1980; 23: 626-32.

10 Miyasaki N, Nakamura T, Russell I J, Talal N. Interleukin 2 deficiencies in rheumatoid arthritis and systemic lupus erythematosus. Clin Immunol Immunopathol 1984; 31: 109-17.

11 Billingham M E J. Models of arthritis and the search for antiarthritis drugs. Pharmacol Ther 1983; 21: 389-428.

12 Rainsford K D. Adjuvant polyarthritis in rats: is this a satisfactory model for screening antiarthritis drugs. Agents Actions 1982; 12: 452-8.

13 Carlson R P, Datko L J, Chang J, Nielsen S T, Lewis A J. The anti-inflammatory profile of (5H-dibenzo[A,D]-cyclohepten-5ylidine) acetic acid (Wy-41,770), an agent possessing weak prostaglandin synthetase inhibitory activity that is devoid of gastric side effects. Agents Actions 1984; 14: 654-61.

14 Gilman S C, Rosenberg J S, Feldman J D. Inhibition of interleukin synthesis and $\mathrm{T}$ cell proliferation by a monoclonal anti-Ia antibody. $J$ Immunol 1983; 130: 1236-40.

15 Gilman S C, Rosenberg J S, Feldman J D. T. lymphocytes of young and aged rats. II. Functional deficits and the role of interleukin 2. J Immunol 1982; 128: 644-50.

16 Dinarello C A. Interleukin 1. Rev Infect Dis 1984; 6: 51-95.

17 Smith K A. T cell growth factor. Immunol Rev 1980; 51: 337-57.

18 Goodwin J S, Webb D R. Regulation of the immune response by prostaglandins. Clin Immunol Immunopathol 1980; 15: 106-22.

19 Rappaport R S, Dodge G R. Prostaglandin E inhibits the production of human interleukin 2. J Exp Med 1982; 155: 943-8.

20 Flower $\mathrm{R}$ J. Drugs which inhibit prostaglandin biosynthesis. Pharmacol Rev 1974; 26: 33-66.

21 Kourounakis L, Kapusta M A. Effect of Freund's adjuvant on the mitogenic response of rat lymphocytes. Ann Rheum Dis 1974; 33: 185-91.

22 Binderup L. Decreased T-suppressor cell activity in rats with adjuvant arthritis. Ann Rheum Dis 1983; 42: 693-8.

23 Binderup L, Bram E, Arrigoni-Martelli E. The effect of some antirheumatic drugs in vivo on the response of spleen cells to concanavalin $\mathrm{A}$ in rats with chronic inflammation. Int $J$ Immunopharmacol 1983; 4: 57-66.

24 Mackaness C B, Lagrange P H, Ishibashi T. The modifying effect of BCG on the immunological function of T cells. $J$ Exp Med 1974; 139: 1540-7. 
25 Geffard M, Orbach-Arbouys S. Enhancement of T suppressor activity by high doses of BCG. Cancer Immunol Immunother 1974; 1: 41-3.

26 Orbach-Arbouys S, Poupon M-F. Active suppression of in vitro reactivity of spleen cells after BCG treatment. Immunology 1976; 34: 431-7.

27 Robb R J, Greene W C. Direct demonstration of the identity of $\mathrm{T}$ cell growth factor binding protein and the TAC antigen. $J$ Exp Med 1983; 158: 1332-7.

28 Chang J, Carlson R P, Lewis A J. Comparative study of the antiflammatory activity of fentiazac and its major metabolite. p-hydroxyfentiazac. Agents Actions in press.

29 Hassler F, Bluestein H G, Zvaifler N J, Epstein L B. Analysis of the defects responsible for the impaired regulation of EBV-induced B cell proliferation by rheumatoid arthritis lymphocytes. II. Role of monocytes and increased sensitivity of rheumatoid arthritis lymphocytes to prostaglandin E. J Immunol 1983; 131: 768-72.

30 Geha R S, Rosen F S. Immunoregulatory T-cell defects. Immunol Today 1983; 4: 233-7.
31 Gilman S C. Lewis A J. Immunomodulatory drugs in the treatment of rheumatoid arthritis. In: Rainsford $\mathrm{K} D$, ed. Antiinflammatory and antirheumatic drugs. London: CRC Press, in press.

32 Alcocer-Varela J, Alarcon-Segovia D. Decreased production of and response to interleukin 2 by cultured lymphocytes from patients with systemic lupus erythematosus. J Clin Invest 1982; 69: $1388-92$.

33 Dauphinee M J, Kepper S B. Wofsy D. Talal N. Interleukin 2 deficiency as a common feature of autoimmune mice. $J$ Immunol 1981; 127: 2483-7.

34 Gillis S, Kozak R, Durante M, Weksler M E. Immunological studies of aging. Decreasing production of and response to $T$ cell growth factor by lymphocytes from aged humans. J Clin Invest 1981; 67: 937-42.

35 Prince H E, Gottlieb M S, Kermani-Arab V, Fehey J L. Interleukin 2 (IL-2) and IL-2 receptor: relationships to defective $T$ cell proliferation in acquired immunodeficiency syndromes (AIDS). Fed Proc 1983; 42: 1344.

36 Gilman S C. Lymphokines in immunological aging. Lymphokine Res 1984; 3: 119-23. 